\title{
プラズマ溶射コーティングの耐食性に及ぼす封孔処理 ならびに組成傾斜化の効果
}

\author{
木村雄二*, 吉 岡 寿 扇** \\ * 工学院大学工学部化学工学科 \\ ** 日本コーティング工業株式会社
}

\section{Effects of Sealing Treatment and Microstructural Grading upon the Corrosion Characteristics of Plasma-Sprayed Ceramic Coating}

\author{
Yuji Kimura* and Toshio Yoshioka** \\ * Dept. Chemical Eng., Kogakuin University. \\ ** Nippon Coating Industry Co. Ltd.,
}

\begin{abstract}
Present authors have investigated the corrosion characteristics of plasma-spray ceramic coated stainless steel by various electrochemical corrosion testings methods. It was indicated that microcracks and micropores in $\mathrm{ZrO}_{2}$ top coated layer play important role as the path through which aqueous solution comes into inner layers. And, intense corrosion was recognized on the interface regions between $\mathrm{ZrO}_{2}$ top coat and $\mathrm{NiCrAlY}$ undercoated layer. In some cases, these corrosion brought about peeling off the top coated layer. Therefore in this paper, to improve corrosion resistance of plasma-sprayed ceramic coating in an aqueous solution environment, sealing treatment and microstructural grading were conducted employing $\mathrm{NiCrAlY}$ and $\mathrm{ZrO}_{2}$ system. Then, several investigations concerning corrosion characteristics of these plasma-sprayed ceramic coating system, were conducted from electrochemical view points. As a result, it was recognized that microstructurally graded coating shows little improvements in the corrosion properties. On the contrary, sealing treatment shows much improvements in corrosion resistance especially in the case when heat treatment was employed at $300^{\circ} \mathrm{C}$ for the period of 2 hours. Then, some evaluations of defect ratio in plasma-spray ceramic coatings were conducted.
\end{abstract}

Key words : plasma-sprayed ceramic coating, sealing treatment, microstructural grading, corrosion characteristics, open pores, microcracks, defect ratio

\section{1. 緒 言}

セラミックスの有する高強度・化学的安定性などの優 れた特性を充分に活用するためには，他の部材との接合 あるいは複合化する技術の早急なる開発の必要性が叫ば れている。そして，セラミック・コーティングもこのよ うな意味合いから重要な技術の一つとなりつつある。

種々のセラミックコーティング手法のうち ${ }^{1)}$, 液体状 の微粒子を加速して基材表面に衝突させ, 偏平粒子の堆 積・積層により皮膜を形成させる溶射コーティング技

* T160 東京都新宿区西新宿 1-24-2（1-24-2, Nishishinjuku, Shinjuku-ku, Tokyo, 160 Japan)

** $\bar{T} 660$ 尼崎市長洲西通 1-10（1-10, Nagasunishidori, Amagasaki, 660 Japan)
術 $^{2)}$ が, 大規模な真空装置を必要としない, 成膜速度が 大きい，ならびに，対象とする材料が限定されず幅広い 分野に応用され得る可能性があるなどの点から, 注目さ れている。その中でも，特に，プラズマ溶射手法が高融 点材料の成膜を可能にし，また，形成された皮膜の緻密 性などの優れた特性から, 溶射コーティングにおいて重 要な地位を築きつつある2)。

前報においては，耐摩耗性と同時に耐食性に対する性 能が求められる部材の表面改質に適用し得るプラズマ溶 射コーティングの腐食抵抗性を， $3 \% \mathrm{NaCl}$ ならびに 1 $\mathrm{N} \mathrm{H}_{2} \mathrm{SO}_{4}$ 水溶液中における 3 電極方式による分極挙動 の測定, 定電位腐食試験 ${ }^{32}$ ならびに $\mathrm{Pt}$ 対極とのカップ リング条件下での腐食試験 ${ }^{4)}$ により評価(た5),6)。その 
Table 1 Conditions of plasma-spray coating.

\begin{tabular}{|l|c|c|}
\hline & Under coat & Top coat \\
\hline Powder & NiCrAIY & ZrO2-8\% Y2 O3 \\
Plasma gun & $\mathbf{7 M}$ & $7 \mathrm{M}$ \\
Plasma current (A) & $\mathbf{5 0 0}$ & $\mathbf{5 0 0}$ \\
Plasma potential (V) & $\mathbf{6 3}$ & $\mathbf{6 3}$ \\
Plasama gas:primary & $\mathbf{A r}$ & $\mathrm{Ar}$ \\
Plasma gas:secondary & $\mathbf{H} 2$ & $\mathbf{H} 2$ \\
Distance (mm) & 120 & $\mathbf{1 2 0}$ \\
Powder feed rate (g/min.) & $\mathbf{7 0} \pm 5$ & $\mathbf{4 0} \pm 5$ \\
Traverse speed (cm/min.) & $\mathbf{3 0}$ & $\mathbf{3 0}$ \\
Pass number (passes) & 2 & $\mathbf{1 4}$ \\
Pitch (mm) & 5 & 5 \\
Thickness (mm) & $\mathbf{0 . 1 2} \pm \mathbf{0 . 0 2}$ & $\mathbf{0 . 2 6} \pm \mathbf{0 . 0 2 5}$ \\
\hline
\end{tabular}

結果, プラズマ溶射コーティング皮膜にとって, トップ コート層に存在する空隙ならびに割れを通して浸透して

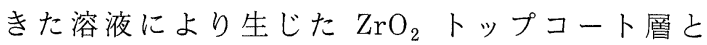
$\mathrm{NiCrAlY}$ 層の界面での腐食損傷が，コーティング皮膜 の特性を決定することが明らかとなった。すなわち，加 熱・冷却に伴い発生する熱応力により溶射コーティング 皮膜に生じる損傷を分類した場合に指摘されている種々 の形態 ${ }^{1)}$ のうち, トップコート層とアンダーコート層の 層間の損傷による機構が，同材料の耐食性を問題にする 場合においても重要であることが示された。これらの結 果より, プラズマ溶射による通常の 2 層コーティング膜 (アンダーコート : $\mathrm{NiCrAlY}$, トップコート : $\mathrm{ZrO}_{2}-8$ $\left.\% \mathrm{Y}_{2} \mathrm{O}_{3}\right)$ 成膜時にトップコート層に形成される空孔な らびに割れの存在が溶射コーティング膜の耐食性を著し く損なう要因として重要であることを明らかにし $た^{5), 6)}$ 。

したがって，これらの空孔ならびに割れの存在による 腐食特性の劣化に対してなんらかの対策を講ずる必要が あるが，その一つとしては，存在する欠陷を耐食性に優 れた物質でシールすることによる特性の改善が考えら れ，また一方では，溶射時にトップコート層に形成され る割れならびに空孔の発生を出来るだけ抑制する方法を 採用することが, 溶射皮膜の耐食性の改善のために必要 不可欠と考えられよう。

そこで本論文では，これらの割れならびに空孔をシー ルするためにエチルシリケートで封孔処理を施した試験 片ならびに成膜時の割れの発生を極力抑制することを意 図して, アンダーコート層である $\mathrm{NiCrAlY}$ からトップ コート層である $\mathrm{ZrO}_{2}$ までの皮膜組成を傾斜化させて成 膜した場合の溶射コーティング皮膜の耐食性に対して, 前報と同様電気化学的手法により検討を行った結果を述 ベる。

\section{2．試験片ならびに実験方法}

SUS 304 鋼の電極型試験片の端面 $(11.3 \phi \times 20 \iota:$ 電
極面積 $\left.1 \mathrm{~cm}^{2}\right)$ に，サンドブラスト（\#60,4.0 kg/ $\mathrm{cm}^{2}$ ) 後にアンダーコートとして NiCrAlY（粒径 : 44 〜 $105 \mu \mathrm{m}$ ）を $120 \mu \mathrm{m}$ 程度の厚みでコーティングし, トップコートとして $\mathrm{ZrO}_{2}-8 \% \mathrm{Y}_{2} \mathrm{O}_{3}$ (粒径 : 10～44 $\mu \mathrm{m}$ ) のコーティング皮膜をプラズマ溶射手法により約 260 $\mu \mathrm{m}$ の厚みで作製した。

また, 封孔処理ならびに皮膜の組成傾斜化の耐食性改 善に対する効果を検討するため, 前述と同様な 2 層構造 の試験片のトップコート層をエチルシリケートにより封 孔処理し一部さらに後熱処理したもの，ならびに SUS 304 鋼の電極型試験片の端面に, サンドブラスト処理後 に, $\mathrm{NiCrAlY}$ から $\mathrm{ZrO}_{2}-8 \% \mathrm{Y}_{2} \mathrm{O}_{3}$ まで, いずれも 10 $\sim 40 \mu \mathrm{m}$ の粒径の粉体を用い, 組成を 10 段階にステッ プ状に変化させた溶射コーティング皮膜を，プラズマ溶 射手法により約 $400 \mu \mathrm{m}$ の厚みで作製した。すなわち， 試料のトラバースを 20 回行う間に，パウダーの供給を NiCrAlY $100 \%$ から $\mathrm{ZrO}_{2}$ 100\%までに 10 段階にス テップ状に変化させた条件下で皮膜を作製した。傾斜化 した皮膜の組成分布については EPMA により検討を加 え, 形成された薄膜中に存在する気孔, 割れなどについ てはSEMにより詳細な観察を行った。

セラミックコーティング面以外はすべてシリコンコー ティングにより遮蔽し, 同電極試験片は $303 \mathrm{~K}$ の $3 \%$ $\mathrm{NaCl}$, ならびに $1 \mathrm{~N} \mathrm{H}_{2} \mathrm{SO}_{4}$ 水溶液 $\left(\mathrm{N}_{2}\right.$ ガスで脱気 $)$ 中で 3 電極方式による, 分極挙動の測定, 定電位腐食試 験ならびに Pt 対極とのカップリング条件下での腐食試 験 ${ }^{3)}$ を行い，コーティング皮膜の腐食抵抗性の評価を試 みた。また, SEMによる詳細な観察から、コーティン グ皮膜の損傷の様相の把握ならびに損傷を支配する因子 について詳細な検討を行った。さらに，溶射皮膜中の貫 通欠陥の存在率について, CPCD (Critical Passivation Current Density）法"7) を用いて評価することを 試みた。

\section{3. 実験結果および考察}

\section{1 コーティング皮膜の構造・形態}

まずはじめに，プラズマ溶射手法により作製した皮膜 組成の傾斜化が実際にどの程度実現されているのかを検 討するために, EPMA により Zr の分布状態の面分析 ならびに線分析を行った結果を Fig. 1 ならびに Fig. 2 に示す。これらの図は, コーティングの表面層から内部 へ向かって $\mathrm{Zr}$ が徐々に減少し，一方 $\mathrm{Ni} ， \mathrm{Al}$ ならびに Cr が徐々に増加しており, 組成傾斜化がある程度実現 されていることを示している。また，コーティング膜の 成膜後の冷却過程で生成されると考えられている割れ， ならびに膜の内部に分布する空孔などの欠陥の状況を確 認するためにコーティング層の断面ならびに表面に対し 


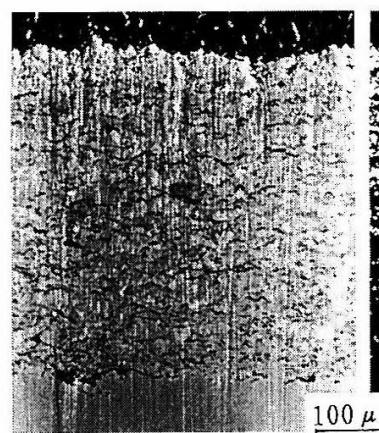

(a)SEM observation

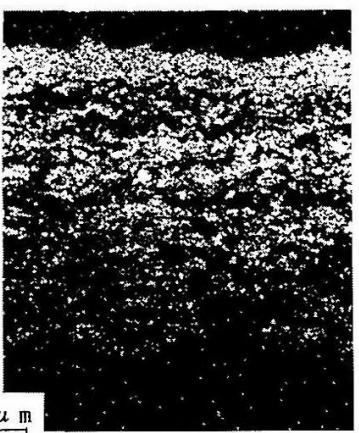

(b) Zr distribution

Fig. 1 Morphologies and Zr distribution in graded coating layer.

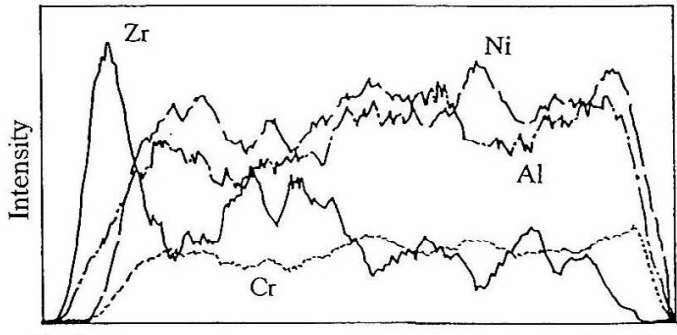

Surface

Boundary

Fig. 2 Results of line analysis by EPMA : Distribution of $\mathrm{Zr}, \mathrm{Ni}, \mathrm{Cr}$ and $\mathrm{AI}$ in graded coating layer.

て SEM により詳細に観察したが，ぞの結果の一部を Fig. 3 (a) (b), Fig. 4 (a) (b) ならびに Fig. 5 (a) (b) に示した。冷却時に発生する熱応力によるトップコート 層のはく離を防ぐために，金属層を中間層として用いて いるのが通常の 2 層構造のコーティング膜であるが, こ れらの畄は，2 層構造のコーディングにおいて，一部ア ンダーコート層とトップコート層の境界に欠俩が存在し ていることを示している。また, $\mathrm{ZrO}_{2}$ 層中に数多く認 められる割れなどの欠俩の生成が，組成の傾斜化により かなり抑制されていることが明らかとなった。

したがって, 従来, 熱応力緩和のために組成の傾斜化 が有効であるとの指摘がなされているが8), 本研究で採 用した比較的単純なステップ状の直線的な組成の傾斜化 によっても，成膜後の冷却過程で生ずる割れの発生を抑 制するなどの効果をもたらしているものと考えられる。

また，一万では，存在する欠陥をシールすることによ る特性の改善を意図し，前述の 2 層コーティングのトッ プコート層に存在する空孔ならびに割れをエチルシリ ケートで封孔妈理したコーティング皮膜を用意した。前 述の Fig. 5 (b) は 2 層溶射皮膜の封孔処理後の表面を 示したものであるが，このような SEM による表面形態


(a) boundary between graded coating and substrate

(b) graded coating layer

Fig. 3 Morphologies of graded coating layers.
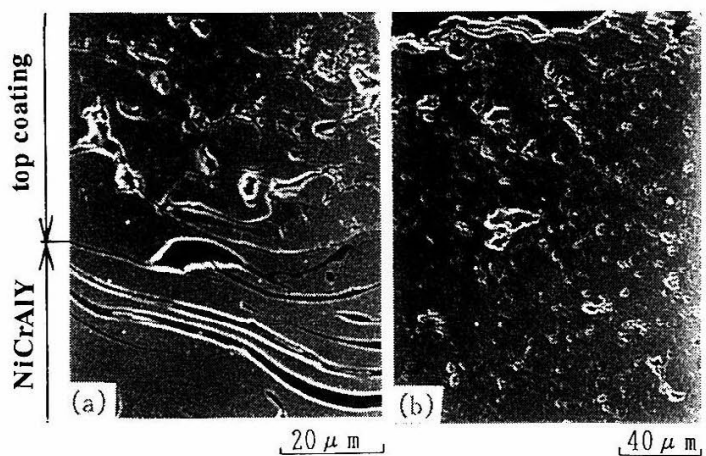

(a) boundary between top coat and NiCrAIY

(b) top coating layer

Fig. 4 Morphologies of usual plasma-sprayed coating layer.

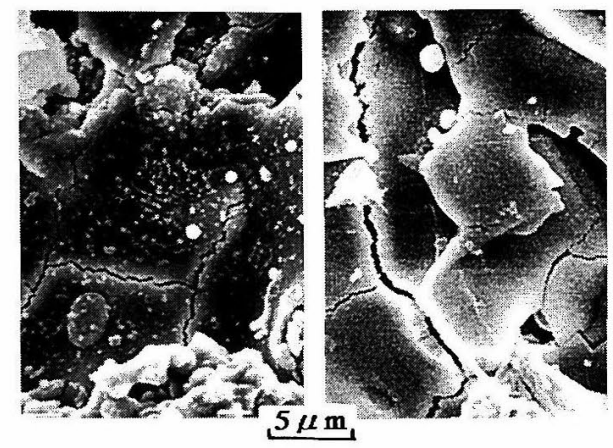

(a) graded coating (b) two layers coating

Fig. 5 Microcracks observed on the surface of coatings.

の観察のみからは，2 層溶射皮膜表面に存在する割れな らびに微細な空隙に封孔処理剤が侵入している状況が必 ずしも明確に確認されなかった。また今回のように，工 チルシリケートによる封孔処理をはけ塗りにより 2 回程 度施した場合, 封孔好理剂が表面より $30 \mu \mathrm{m}$ 程度の深 さにまで侵入すると言われている2)。そこで，この点の 


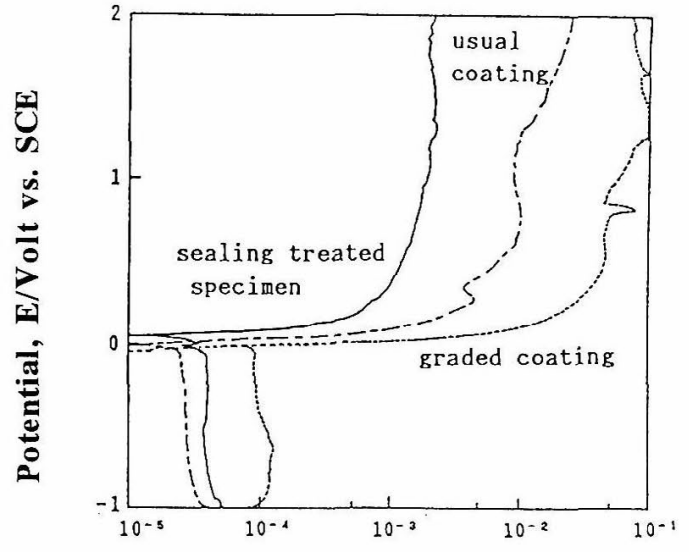

Current density, | i | /A cm-2

Fig. 6 Polarization curves of specimens in $3 \% \mathrm{Na}$ $\mathrm{Cl}$ aqueous solution : sweep rate $20 \mathrm{mV} /$ min.

確認のために，刲孔処理材については，封孔処理後に コーティング層の断面をとり，EPMA により封孔処理 剤の主成分である Si の分布深さなどの検出を試みたが, 現状では封孔処理剂の侵入深さに関するデー夕を得るに 至っていない。したがって，これらの点については今後 さらに検討を加えていく予定である。

\section{2 皮膜組成の傾斜化によるの耐食性の変化}

本節では，成膜時の割れの発生を極力抑制することを 意図して，アンダーコート層である $\mathrm{NiCrAlY}$ からトッ プコート層である $\mathrm{ZrO}_{2}$ までの皮膜組成を傾斜化させ成 膜した場合のコーティング皮膜の耐食性について，前 報 ${ }^{5)}$ と同様に電気化学的な手法を中心として検討した結 果を述べる。

前報5),6) の結果からも, $1 \mathrm{~N} \mathrm{H}_{2} \mathrm{SO}_{4}$ 水溶液に比較して $3 \% \mathrm{NaCl}$ 水溶液の方がプラズマ溶射コーティング材に 対してより苛酷な環境であることが明らかであるので, ここではまず， $303 \mathrm{~K}$ の $3 \% \mathrm{NaCl}$ 水溶液中の分極挙動 について調べた。試験片を同溶液に 30 分間浸漬し自然 電極電位 (N.P.) を測定後, JIS の孔食電位測定法 ${ }^{9}$ ) に基づきー1〜+2Volt(SCE) まで $20 \mathrm{mV} / \mathrm{min}$ の掃引 速度で分極曲線(-0)を求めた。その結果のうち代表的なも のをFig. 6 に示した。また, 同図には, 後述する封孔 処理材に対して求めた分極曲線を併記してある。同図 は, 皮膜組成の傾斜化により, アノドー分極曲線が立ち 上がる電位（電流密度 $i=100 \mu \mathrm{A} / \mathrm{cm}^{2}$ よなる電位であ る孔食電位などで評価）が多少䖝側にシフトし，また次 節で詳細に述べるように，1.5 Vにおけるアノード電流 值を比較すると，通常の 2 層コーティングに比較して 1/10 以下に抑えられている封孔処理材は勿論のこと,

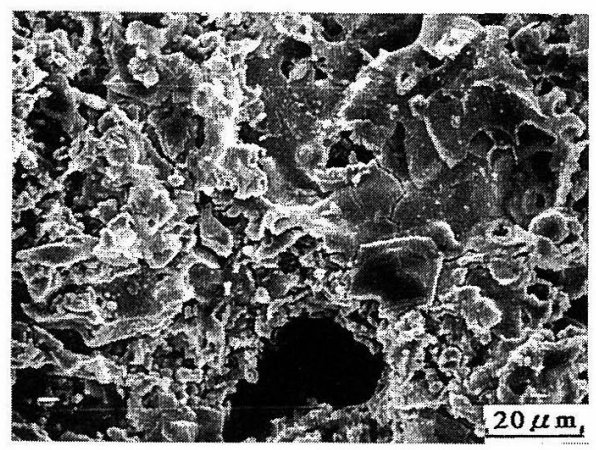

Fig. 7 Morphologies of corrosion observed in graded coating layer after the polarization test in $3 \% \mathrm{NaCl}$ aqueous solution by sweeping the potential to $E=+2.0$ Volt (SCE).

処理をしていない通常の 2 層コーティング材よりも更に 5 倍以上大きくなっており, 組成の傾斜化が耐食性の改 善には全く奇与していないことを示している。そして,

下地の NiCrAIY が表面層近傍にまで存在することによ る腐食抵抗性の劣化の方がむしろ著しいことが明らかで ある。そこで, 試験片に流れる電流値の差哄が明膫とな る定電位条件である $E=+1.5 \mathrm{Volt}$ (SCE) で, 120 分 間の定電位電解を行ったとき流れる電流密度値の経時変 化を検討した。前述の場合と同様に傾斜組成試験片の場 合にその值が著しく大きくなり，この場合も同材におい ては通常の 2 層皮膜構造試験片に比較して耐食性が悪化 することが明らかとなった。そしてこれいの腐食試験 の際に, 腐食損傷が著しい場合には, 電極表面層の $\mathrm{Zr}$ 層の部分が一部剝がれ落ちる場合も観察された。そこ で，100\% Zr である表面層が剝がれ落ちた後の表面を SEMにより詳細に観察した結果を Fig. 7 に示した。同 図上り組成傾斜材の前述の分極曲線测定時ならびに定電 位条件下における著しい電流密度の増加が，傾斜組成層 を形成している成分のうち NiCrAlY の腐食溶解による ことが確認される。

しかしながら，Fig. 8 に示した $3 \% \mathrm{NaCl}$ 水溶液中な らびに $1 \mathrm{~N} \mathrm{H}_{2} \mathrm{SO}_{4}$ 水溶液中での電位を印加しない $\mathrm{Pt}$ 対極とのカップリング条件下での, 腐食電位の経時変化 の挙動ならびに試験片と Pt 対極間で計測される電流密 度の最大值については, 非傾斜材 (2 層材) と比較して 組成傾斜化の効果が幾分認められた。この上うな $\mathrm{Pt}$ 対 極々のカップリング条件下での特性の改善は, 前節の Fig. 3 および 5 に示したコーティング層中におけるマ イクロクラックなどの欠陷の発生が抑制された事実と密 接な関係があるものと考えられる。

したがって，貴側の高いアノード電位を強制的に印加 した場合は傾斜組成層の NiCrAlY のアノード溶解が生 
じ耐食性が劣化するが, Pt 対極とのカップ リング条件下での腐食溶解のように電流密度 が小さくしたがって著しい腐食の生じない場 合には, 組成傾斜化による皮膜の割れ発生の 抑制が耐食性の改善に対してある程度有効で あることを,これらの結果は示唆しているも のと考えられる。

\section{3 封孔処理ならびに後熱処理による コーティング皮膜の耐食性改善}

本節では，存在する欠陥をシールすること による特性の改善を意図し, 前述の 2 層コー ティングのトップコート層に存在する空孔な らびに割れをエチルシリケートで封孔処理し たコーティング皮膜の耐食性ならびに, 封孔 処理材に対して $200 \sim 500^{\circ} \mathrm{C}$ の温度範囲で大 気環境中 2 時間保持の後熱処理を行い, 封孔 処理剤成分を無機化（ガラス化）させた試験 片における耐食性の改善の程度を同様に電気 化学的手法により検討した結果を述べる。

すなわち, Fig. 9 には $300 〜 500^{\circ} \mathrm{C}$ の範囲 で種々の温度条件下での後熱処理後に $3 \%$ $\mathrm{NaCl}$ 水溶液中で分極曲線を求めた結果を示 す。同図と前述の Fig. 6 から, 封孔処理に より, 非処理材に比較してアノード分極曲線 が立ち上がる電位（孔食電位などで評価）が

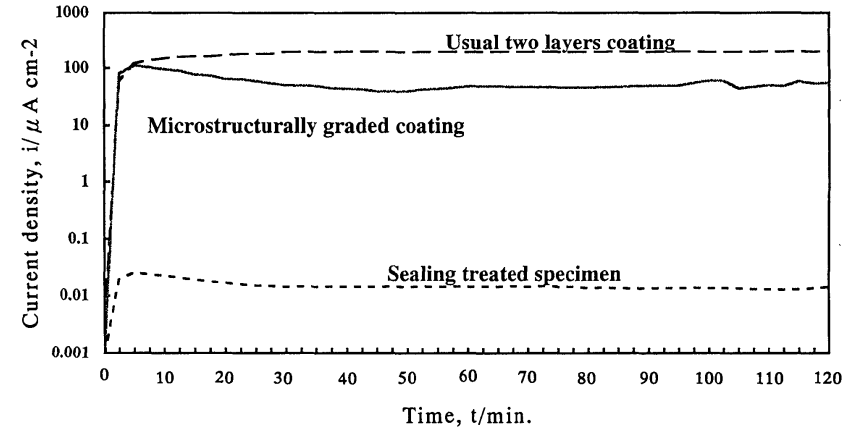

(a) Current density

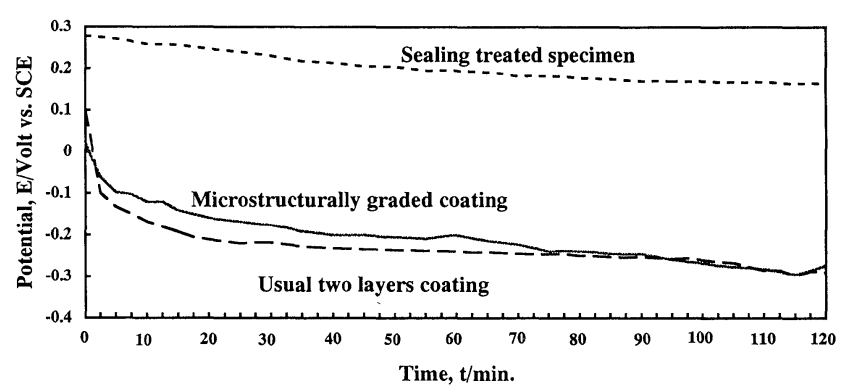

(b) Potential

Fig. 8 Changes in potentials and current densities detected under coupling condition between test specimen and counter electrode of $\mathrm{Pt}$ in $3 \% \mathrm{NaCl}$ aqueous solution.
より貴側にシフトしさらに頭打ちとなる電流

密度の值が $1 / 10$ 程度に小さくなり, 耐食性が著しく改 善されていることが示された。そして, 特に封孔処理後 $300^{\circ} \mathrm{C} 2$ 時間の後熱処理を施した場合に, 孔食電位の值 に対する改善の程度がさらに顕著となることが明らかで ある。しかしながら, $500^{\circ} \mathrm{C}$ の後熱処理を施した場合に は,これらの特性がかえって悪化し, 封孔処理を施さな い場合と同程度まで耐食性が低下することも示されてい る。すなわち, $300^{\circ} \mathrm{C}$ 以上の温度での後熱処理により封 孔処理剂自身は無機化されより堅固なガラス質のシール が実現されるが，加熱による無機化に伴うシール剂の大 きな収縮によりシール部分に再び割れが生成されたため にかえって耐食性が劣化するような結果をもたらしてい るものと考えられる。そして，このような封孔好理によ る耐食性の改善は, $E=+1.5 \mathrm{Volt}(\mathrm{SCE})$ の定電位条 件下でも特に $3 \% \mathrm{NaCl}$ 水溶液環境下で同様に確認され た。また, $3 \% \mathrm{NaCl}$ 水溶液ならびに $1 \mathrm{~N} \mathrm{H}_{2} \mathrm{SO}_{4}$ 水溶液 中における $\mathrm{Pt}$ 対極とのカップリング条件下の腐食試験 時の腐食電位ならびに試験片と $\mathrm{Pt}$ 対極間で検出される 電流密度值の経時変化についても検討を加えたが, ここ でも封孔処理 (シリカ処理) の効果は明瞭であり, 自然 電極電位はトップコートの $\mathrm{ZrO}_{2}$ の電位により支配され

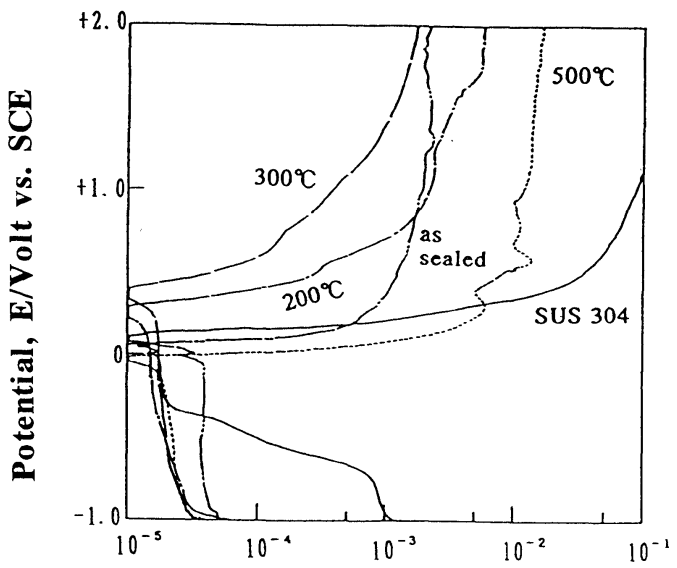

\section{Current density, | i | /A cm-2}

Fig. 9 Cathodic and anodic polarization curves of specimens obtained in $3 \% \mathrm{NaCl}$ aqueous solution.

る結果として卑側へのシフトは小さく，またトップコー トの欠陥部がシールされることにより対極との間に流れ 


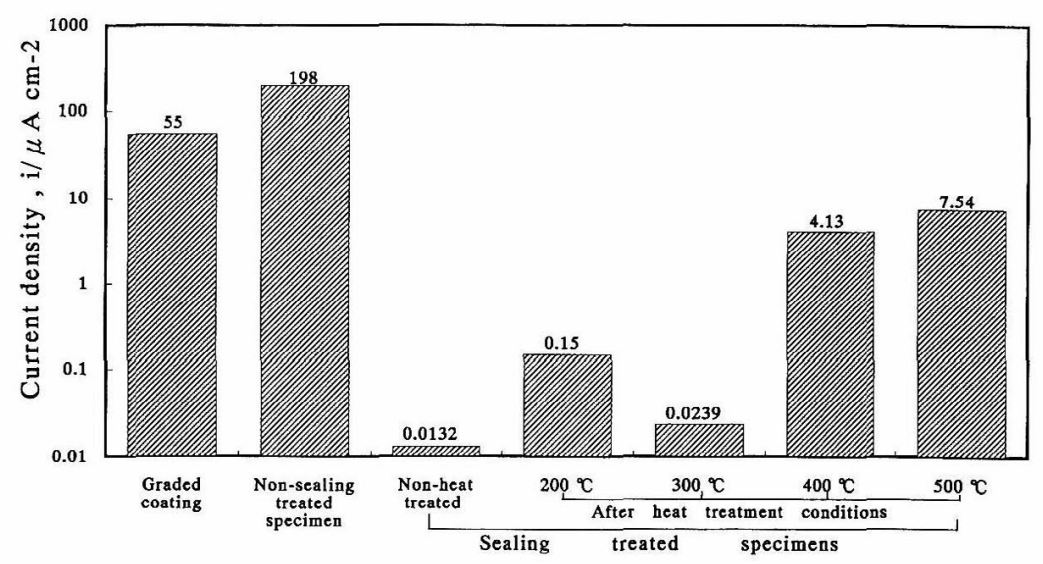

Fig. 10 Maximum current densities detected under coupling condition between coated specimens and counter electrode of $\mathrm{Pt}$ in $3 \% \mathrm{NaCl}$ aqueous solution during 2 hours testing.

る電流密度も小さくなり (Fig. 8)，1/1000 程度に抑え られることが明らかとなっている(Fig.10)。またこ の場合についても, 後熱処理の効果を特に $3 \% \mathrm{NaCl}$ 水 溶液環境中で検討したが，その結果のうち同環境中に2 時間浸漬後の電流密度の値をまとめ, Fig.10に示した。 その結果, $300^{\circ} \mathrm{C}$ の後熱処理の場合には熱処理を施さな い試験片と同程度の特性を示していることが明らかと なった。そこで，ここでも，腐食試験後に断面をとり， 腐食の進行の状況を観察したが, その結果のうちの代表 的なものを Fig.11に示す。同図は, $3 \% \mathrm{NaCl}$ 水溶液中 において $E=+1.5 \operatorname{Volt}(\mathrm{SCE})$ で 2 時間の定電位電解 後の形態を示すが，断面上に特に明らかな将食の痕跡は 認められず，封孔処理の效果が確かなものであったこと がこの点からも確認されている。

以上の上うに, 封孔処理による耐食性改善の程度を把 握するために，アノード分極曲線における頭打ちになる 電流密度ならびに $\mathrm{Pt}$ 対極とのカップリング条件下にお ける電流密度などを比較検討した結果, 改善の著しいこ とが明らかであった。したがって封孔処理ならびに $300^{\circ} \mathrm{C}$ 程度の後熱処理を施すことにより，コーティング 皮膜の耐食性が著しく改善されることが示された。

\section{4 プラズマ溶射皮膜の欠陥評価}

本節では, 封孔処理によりコーティング皮膜中に存在 する割れおよびマイクロポアなどがどの程度シールされ ているのかについて定量的に検討するために, 溶射皮膜 中の貫通欠宿の存在率の評価を試みた。

これまで一般に, 膜の有孔度試験法としてフェロキシ

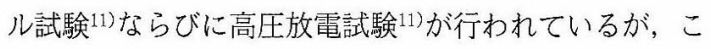
れらの手法は結果の定量性・再現性などに多くの問題を 抱えている現状にある。また現在までに，CVDならび

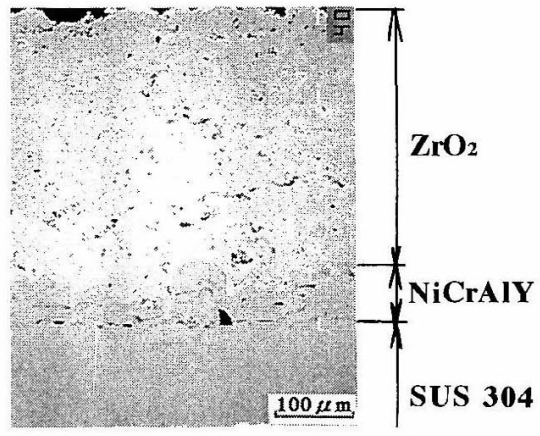

Fig. 11 Morphologies of cross section of sealing treated specimen after potentiostatic corrosion test of $E=+1.5 \mathrm{~V}$ (SCE), 2 hours in $3 \% \mathrm{NaCl}$ aqueous solution.

にPVDにより作製された膜厚 $2 \mu \mathrm{m}$ 程度の薄膜の電気 化学的な欠陷評価手法の一つとして $0.5 \mathrm{kmol} / \mathrm{m}^{3}$ $\mathrm{H}_{2} \mathrm{SO}_{4}+0.05 \mathrm{kmol} / \mathrm{m}^{3}-\mathrm{KSCN}$ 水溶液を用いた $\mathrm{CPCD}$ (Critical Passivation Current Density) 法 ${ }^{12)}$ の有用 性が指摘されている。そして, 同手法はすでに制定され ている日本機械学会基準「ドライコーティング膜の欠陥 評価試験法」7 の一部にも含まれている。そこで, 同手 法を下地層 $\mathrm{NiCrAlY}$, トップコート層 $8 \% \mathrm{Y}_{2} \mathrm{O}_{3}-\mathrm{ZrO}_{2}$ の 2 層溶射コーティングならびに前述のようにエチルシ リケートで封孔処理した 2 層溶射皮膜の貫通欠陥率の評 佂に適用し, 貫通欠宿の存在率の決定亡封孔処理による その改善の程度の把握を試みた。その結果を Fig.12に 示すが, 下記の式(1) により決定されるトップコート の欠陥面積率 ${ }^{7)}$ が大気溶射皮膜で約 $R=5.40 \%$ である ことが明らかになり，一方封孔処理された 2 層溶射皮膜 


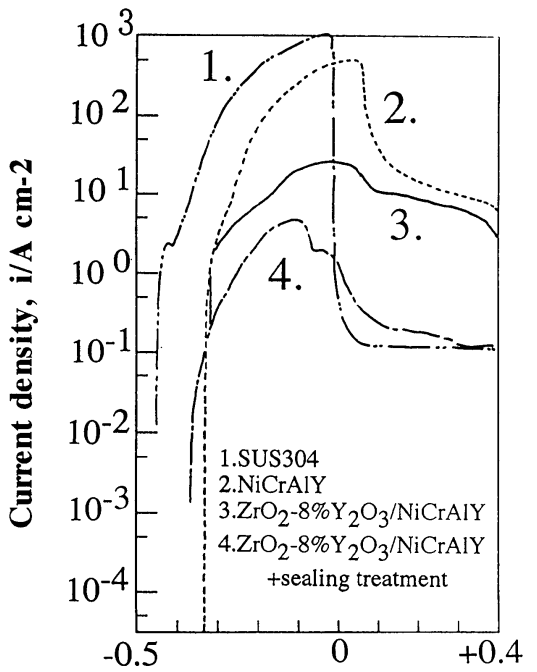

Potential, E/Volt vs. Ag/AgCl

Fig. 12 Anodic polarization curves of specimens : in $0.5 \mathrm{kmol} / \mathrm{m}^{3}-\mathrm{H}_{2} \mathrm{SO}_{4}+0.05 \mathrm{kmol} / \mathrm{m}^{3}-$ $\mathrm{KSCN}$ aqueous solution at $298 \mathrm{~K}$.

においてはこの值が約 $1 / 4$ 程度に低減することが示さ れた。

$R=F \times \frac{i_{\mathrm{CRIT}}\left(\mathrm{ZrO}_{2} / \mathrm{NiCrAlY} / \text { Substrate }\right)}{i_{\mathrm{CRIT}}(\mathrm{NiCrAlY} / \text { Substrate })} \times 100[\%]$

ここで, $i_{\mathrm{CRIT}}\left(\mathrm{ZrO}_{2} / \mathrm{NiCrAlY} /\right.$ Substrate $)$ は 2 層コー ティング試験片の臨界不働態化電流密度であり, $i_{\mathrm{CRIT}}$ (NiCrAlY/Substrate) は NiCrAlY のみをコーティ ングした試験片におけるその值である。また，腐食ピッ 卜形状に関する係数である $F$ の値として $F=1 / 2$ を用い た ${ }^{12)}$ 。したがって, エチルシリケートによる封孔処理 は, 皮膜に存在する貫通欠陥の存在率を低減するのに有 効な手法であることが明らかとなった。またこのように 貫通欠陥率を低減することにより，封孔処理材において は前述した著しい耐食性の改善がもたらされているもの と考えられる。

\section{4. 結言}

耐摩耗性と同時に耐食性に対する性能が求められる部 材の表面改質に適用し得るプラズマ溶射による 2 層コー ティングのトップコート層を封孔処理した試験片ならび にアンダーコート層である $\mathrm{NiCrAlY}$ からトップコート 層である $\mathrm{ZrO}_{2}$ までの皮膜組成を傾斜化させた場合の コーティング皮膜の構造，皮膜の耐食性ならびに欠陷の
存在率について検討した結果, 以下の事柄が明らかと なった。

（1） $\mathrm{NiCrAlY}$ から $\mathrm{ZrO}_{2}$ までの皮膜組成を傾斜化 させた傾斜組成皮膜においては，割れなどの欠陥の生成 が抑制されている。しかしながら，皮膜組成の傾斜化に よっては，Pt 対極とのカップリング条件下における腐 食電流密度の多少の改善を除いて, 期待するほどの耐食 性の改善が実現されていない。

（2）封孔処理による耐食性改善の効果は顕著であり, さらに封孔処理後に $300^{\circ} \mathrm{C}$ での後熱処理を行ったコー ティング皮膜は，耐食性の点でかなりの改善が期待でき ることが示された。

(3) CPCD (Critical Passivation Current Density）法による溶射皮膜の貫通欠陥率の定量的評価の可能 性が示された。また，封孔処理により貫通欠陥の存在率 が約 $1 / 4$ 程度に低減した。

本研究は, 2 年間にわたる文部省科学研究費補助金 (平成 7 年度 : 一般研究 (B), 平成 8 年度 : 基盤研究 （B）一般, 研究課題番号 07455057）の援助を受けて実 施されたものである。記して謝意を表する。

(Manuscript received November 11, 1996 ; in final form December 2, 1996)

\section{参 考 文 献}

1 ）竹田博光 : 「セラミックコーティング」, 日刊工 業新聞社 (1988).

2 ）荒井吉明：「セラミック溶射と応用」，日刊工業 新聞社 (1990).

3 ) 逢坂哲彌・小山 昇 : 「電気化学測定法一応用測 定マニュアル」，講談社，第 5 章 (1990).

4 ）新田誠司，木村雄二：材料之環境，45［7］412 (1996)

5 ）木村雄二, 矢ケ崎隆義, 吉岡寿扇, 金沢 基 : 材 料, 41 [465] 945 (1992).

6) Y. KIMURA, et al. : Advanced Materials '93, I/A : Ceramics, Powders, Corrosion and Advanced Processing, Edited by Mizutani, N. et al., Trans. Mat. Res. Japan, 14 A, p.211, Elsevier Science (1994).

7 ）日本機械学会基準：ドライコーティング膜の欠陥 評価試験法, 日本機械学会 (1996).

8 ) J. Teraki, T. Yamada and T. Hirano : Proc. The First Int. Sympo. on Functionally Gradient Materials, 37 (1990).

9 ) JIS G 0577 ステンレス鋼の孔食電位測定方法.

10) M. Stern and A. L. Geary : J. Electrochemical Soc., 104 [1] 56 (1957).

11）JIS H 8666 セラミック溶射試験方法.

12）杉本克久：「第 95 回腐食防食シンポジウム資 料」, p.1，腐食防食協会（1993）。 